\title{
Pendidikan Kesehatan: Terapi Tawa Sebagai Upaya Mengatasi Kecemasan dan Stres Pada Mahasiswa Mapala Unjani Yogyakarta
}

\author{
Afi Luthfiyati ${ }^{1}$, Dwi Yati ${ }^{2}$ dan Sujono Riyadi ${ }^{3}$ \\ ${ }^{1,2.3}$ Program Studi Keperawatan (S1), Fakultas Kesehatan, Universitas Jenderal Achmad Yani, \\ Yogyakarta, Indonesia \\ e-mail: $\underline{\text { 1_lluth77@yahoo.com, }}{ }^{2}$ dwie.ns215@gmail.com, ${ }^{3 \text { sujono_kmpk2005@yahoo.com }}$
}

\begin{abstract}
ABSTRAK Stres merupakan suatu respons adaptif terhadap situasi yang dirasakan menantang atau mengancam kesehatan seseorang. Pengabdian kepada masyarakat ini berfokus pada kesehatan mahasiswa pecinta alam. Tujuan dari pengabdian kepada masyarakat ini adalah untuk meningkatkan pengetahuan mahasiswa tentang cara mengatasi kecemasan dan stres secara benar dengan cara menerapkan terapi tawa. Metode yang digunakan dalam pengabdian masyarakat ini berupa ceramah dan diskusi serta praktik tertawa agar tubuh menjadi rileks. Dari 22 mahasiswa Mapala yang telah mengikuti kegiatan, memperoleh tambahan pengetahuan sebesar $10 \%$ sebanyak sembilan orang, 20\% sebanyak tujuh orang, dan sebanyak enam orang lainnya tidak ada peningkatan pengetahuan. Terapi tawa sebaiknya selalu di aplikasikan dalam setiap kegiatan Mapala.
\end{abstract}

KATA KUNCI: Stres; Terapi tawa

ABSTRACT Stres is an adaptive response to situations that are felt to be challenging or threatening one's health. Community service focuses on the health of nature-loving students. The aim of community service is to increase student knowledge about how to properly deal with anxiety and stres by applying laughter therapy. The methods used in this community service are lectures and discussions as well as the practice of laughter so that the body relaxes. The 22 Mapala students who have participated in the activity, gained additional knowledge by $10 \%$ by nine people, $20 \%$ by seven people, and as many as six other people there was no increase in knowledge. Laughter therapy should always be applied in every Mapala activity.

KEYWORDS: Stres; Laughter therapy.

\section{Pendahuluan}

Cemas secara fisiologis dapat merangsang hipotalamus untuk bekerja secara langsung dalam sistem saraf otonom dan dapat meningkatkan kerja dari sistem saraf simpatis. Bagian dari sistem saraf otonom berfungsi untuk meningkatkan frekuensi denyut jantung serta meningkatkan resistensi vaskuler dan jika didalam tubuh terjadi peningkatan beban kerja jantung maka kebutuhan oksigen ke jantung mengalami peningkatan [1]. Cemas juga dapat mengaktifkan hormon kortisol dan memengaruhi sistem endokrin. Cemas dapat mengaktifkan amigdala yang dapat menstimulasi sistem hormonal dalam hipotalamus dan merangsang dikeluarkannya hormon CRF (corticotrophin releasing factor) hormon ini akan menstimulasi hipofisis untuk melepaskan hormon lain yaitu ACTH (adrenocorticotropic hormon) ke dalam darah dan akan menstimulasi kelenjar adrenal untuk 
menghasilkan kelenjar kortisol [2]. Cemas merupakan tahapan awal seseorang menjadi stres sehingga dapat memicu terjadinya masalah pada kardiovaskuler. Stres menjadi akibat dari hal-hal yang bersifat emosional, sosio kultural, dan okupasional berpengaruh terhadap hipertensi [3].

Pertimbangan yang digunakan untuk menggambarkan hubungan antara kondisi sosial seseorang dengan kesehatannya sangat dianjurkan, karena seseorang yang sehat mental akan bereaksi dengan cara yang positif dalam banyak situasi. Sering munculnya prasangka buruk (negative thinking) akan menciptakan kecemasan dalam diri. Tanda dan gejala seseorang mengalami stres yaitu, sakit kepala, nyeri jantung, jantung berdebar-debar, keluar keringat dingin, sulit tidur, gelisah [4], hilang rasa humor, agresif, apatis, sering melamun, sulit berkonsentrasi, dan lain sebagainya [5]. Berdasarkan wawancara dengan tiga Mahasiswa Pecinta Alam (Mapala) yang merupakan salah satu Unit Kegiatan Mahasiswa yang berorientasi pada kecintaan terhadap alam serta lingkungan di lingkungan Fakultas Kesehatan Universitas Jenderal Achmad Yani Yogyakarta menyebutkan bahwa salah satu kegiatan yang dilakukan adalah mountaineering (pendakian), climbing (pemanjatan), proxicing reclimbing (menuruni goa/ketinggian). Dalam melaksanaan kegiatan tersebut sering dijumpai mahasiswa yang mengalami stres dan kecemasan dan berakhir dengan gangguan kardiovaskuler seperti hipertensi. Hasil penelitiana yang dilakukan oleh Anwar (2015) bahwa perlunya terapi psikologis yang murah, praktis dan ekonomis dalam membantu menangani masalah stress dan kecemasan akibat dari padatnya kegiatan maupun adanya trauma akibat adanya bencana [6].

Faktor risiko yang terjadi dengan gangguan sistem kardiovaskuler adalah kurangnya persiapan mental, fisik, kesehatan dan gaya hidup yang kurang baik. Dalam segi kesehatannya ditemukan bahwa mahasiswa yang mengikuti kegiatan pecinta alam (Mapala) masih belum benar-benar memperhatikan kesehatannya guna meminimalisir risiko terjadinya gangguan kardiovaskuler seperti hipertensi. Sedangkan untuk persoalan yang dihadapi saat ini adalah mahasiswa kurang mengetahui faktor psikologis gangguan kardiovaskuler yang ditimbulkan karena melakukan kegiatan mountaineering (pendakian), Climbing (pemanjatan), proxicing reclimbing (menuruni goa/ketinggian) secara terus menerus tanpa persiapan pencegahan faktor risiko yang matang. Pencegahan yang kurang tepat dapat mengakibatkan gangguan pada sistem kardiovaskuler, salah satunya seperti hipertensi.

Berdasarkan masalah yang telah dikemukakan sebelumnya, maka tujuan pengabdian kepada masyarakat ini adalah untuk meningkatkan pemahaman dan keterampilan mahasiswa yang mengikuti kegiatan pecinta alam (Mapala) di lingkungan Universitas Jenderal Achmad Yani Yogyakarta dalam memahami serta menerapkan terapi tawa sebagai salah satu cara untuk mengatasi kecemasan dan stres yang merupakan faktor risiko psikososial penyakit hipertensi. Hal ini sebagai upaya untuk mengurangi angka morbiditas dan mortalitas. Dalam hal inilah penulis memberikan Pendidikan Kesehatan dan pelatihan berkaitan dengan terapi tawa sebagai salah satu cara untuk mengatasi kecemasan dan stres yang merupakan faktor risiko psikososial penyakit hipertensi. Dengan terapi yang tepat maka kemungkinan terjadinya masalah kardiovaskuler seperti hipertensi akan terhindar. Kegiatan ini penting dilakukan untuk meningkatkan pengetahuan mahasiswa pecinta alam untuk mengatasi kecemasan dan stres sehingga dapat mempersiapkan diri secara mental pada saat kegiatan mendaki gunung. 


\section{Metode}

Pada tahap awal tim pengabdian masyarakat melakukan studi pendahuluan dilanjutkan dengan persiapan. Selanjutnya penulis mempersiapkan perizinan untuk melakukan kegiatan Pendidikan kesehatan (Penkes) kepada Dekan Fakultas Kesehatan Universitas Jenderal Achmad Yani Yogyakarta. Setelah melakukan pengkajian data serta persiapan teknis lainnya seperti materi dan media yang akan digunakan dalam penkes, Langkah berikutnya adalah memberitahukan kepada mahasiswa pecinta alam (Mapala) untuk waktu pelaksaan tersebut. Tahap kedua merupakan pemberian pendidikan kesehatan tentang cara mengatasi kecemasan dan stres pada mahasiswa pecinta alam (Mapala) yang dilaksanakan pada hari Jum'at, 12 Oktober 2018 mulai Pukul 19.00-20.10 WIB bertempat di Ruang Kelas Fakultas Kesehatan Universitas Jenderal Achmad Yani Yogyakarta.

Sebelum materi pendidikan kesehatan diberikan, dilakukanlah pretest terlebih dahulu untuk mengetahui tingkat pemahaman mahasiswa Mapala terhadap tindakan apa yang biasa dilakukan untuk mengatasi kecemasan dan stres sebelum pendakian, dengan harapan pasca pemberian penyuluhan dapat meningkatkan pengetahuan mahasiswa mapala tentang terapi tawa yang benar, sehingga nantinya ada perubahan perilaku bagi mahasiswa pecinta alam (Mapala) dalam kehidupan seharihari dalam mengatasi kecemasan dan stres. Tahap akhir dalam kegiatan ini adalah memberikan postest berupa pertanyaan terkait masalah psikososial dan cara penanganan kecemasan dan stres yang salah satunya dengan terapi tawa. Lebih jelasnya dapat dilihat pada Gambar 1 dibawah ini.

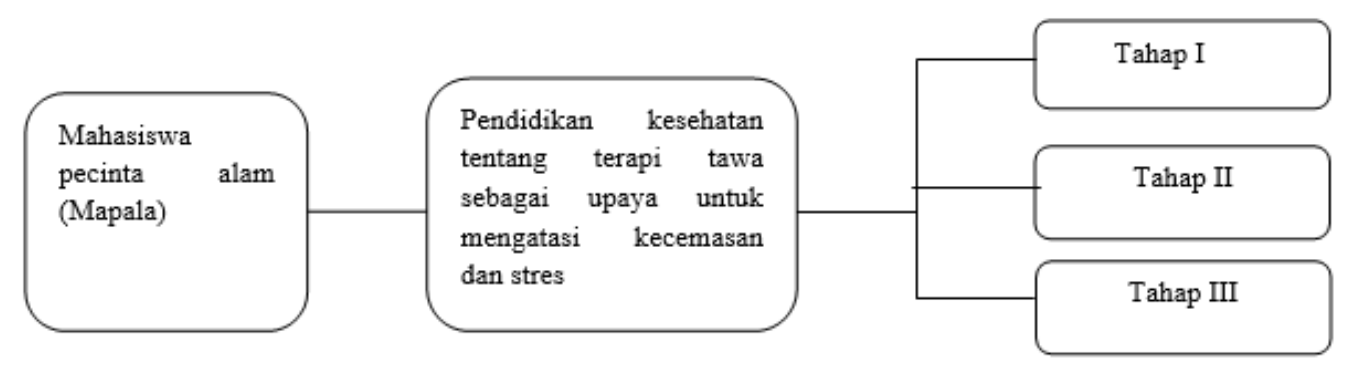

Gambar 1. Kerangka Konsep Metode Pelaksanaan Terapi Tawa

\section{Hasil dan Pembahasan}

Kegiatan pengabdian masyarakat ini sasarannya adalah seluruh Mahasiswa Fakultas Kesehatan Universitas Jenderal Achmad Yani Yogyakarta yang tergabung dalam Unit Kegiatan Mahasiswa (UKM Mapala). Ada 30 mahasiswa yang diundang untuk mengikuti pelatihan terapi tawa, akan tetapi hanya 22 orang yang datang pada saat pertemuan dilaksanakan. Untuk mengetahui pengetahuan Mapala tentang terapi tawa sebagai salah satu cara untuk mengatasi kecemasan dan stres yang merupakan faktor risiko psikososial penyakit hipertensi, maka sebelum kegiatan pelatihan dilakukan pretest, selesai kegiatan dilakukan posttest.

Berdasarkan hasil pre test dari 10 pertanyaan yang diajukan terdapat satu orang menjawab dengan nilai terendah 40 dan satu orang menjawab soal dengan semua benar dengan nilai tertinggi 100 . Hal ini memperlihatkan bahwa pengetahuan mahasiswa tentang terapi tawa sebagai salah satu cara untuk mengatasi kecemasan dan stres yang merupakan faktor risiko psikososial penyakit hipertensi masih kurang memadai. Sedangkan setelah diberikan penjelasan dan demontrasi, dari hasil pos test peserta mampu menjawab semua soal dengan benar dengan nilai 100 sebanyak 11 orang. Untuk lebih jelasnya dapat di lihat pada gambar 2 berikut ini. 


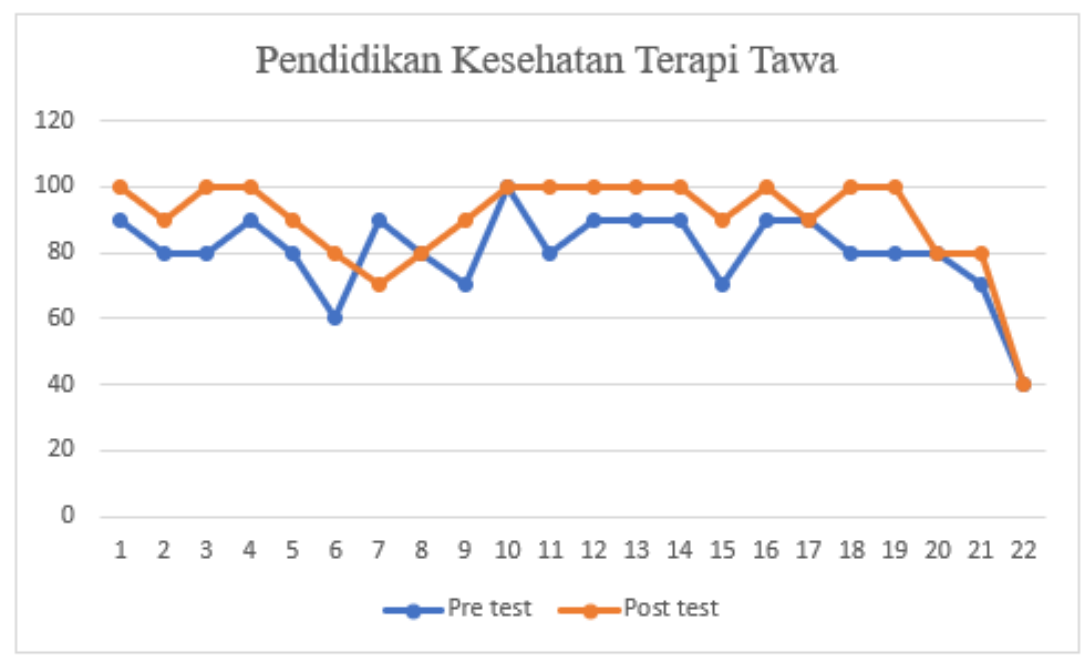

Gambar 2. Pengaruh Pendidikan Kesehatan: Terapi Tawa Terhadap Tingkat Pengetahuan Mapala Unjani Menunjukkan Pengaruh yang Positif dalam Menurunkan Stres

Setelah pelaksanaan pelatihan terapi tawa, terlihat peningkatan pengetahuan mahasiswa secara signifikan. Mahasiswa telah memperoleh tambahan pengetahuan sebesar 10\% sebanyak sembilan orang, 20\% sebanyak tujuh orang, dan $0 \%$ sebanyak enam orang. Metode terapi dengan humor dan tawa dapat membantu individu maupun kelompok untuk menyelesaikan masalah yang ada, termasuk juga mampu dalam menangani masalah gangguan fisik maupun mental [7]. Dari hasil wawancara terhadap tiga peserta pelatihan, mereka menyampaikan manfaat yang diperoleh setelah mengikuti pelatihan terapi tawa. Mahasiswa merasa senang mendapatkan ilmu yang dapat diterapkan pada saat kegiatan Mapala dilakukan. Terapi tawa ini juga bagus diterapkan pada mahasiswa yang sedang menjalani banyak kegiatan seperti ujian semester maupun ujian akademik lainnya [8], Adanya respon psikologis yang menandakan diri dalam keadaan bahaya yang di ekspresikan dengan suatu penghayatan khusus dari individu [9] dapat mengasah sensitifitas personal mapala. Hal ini sesuai hasil penelitian [3] yang mengatakan bahwa terapi tawa memiliki dampak psikologis dan fisologis, terkait stres, efikasi diri, dan dapat menurunkan tekanan darah. Manfaat lain dari terapi tawa ini bahkan dapat meringankan dan bahkan menghilangkan depresi yang terjadi pada lansia [10].

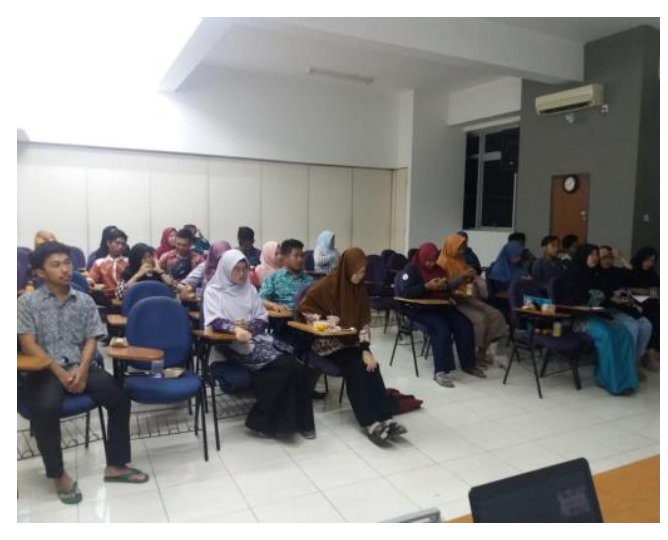

Gambar 3A. Fokus \& Rileks saat kegiatan

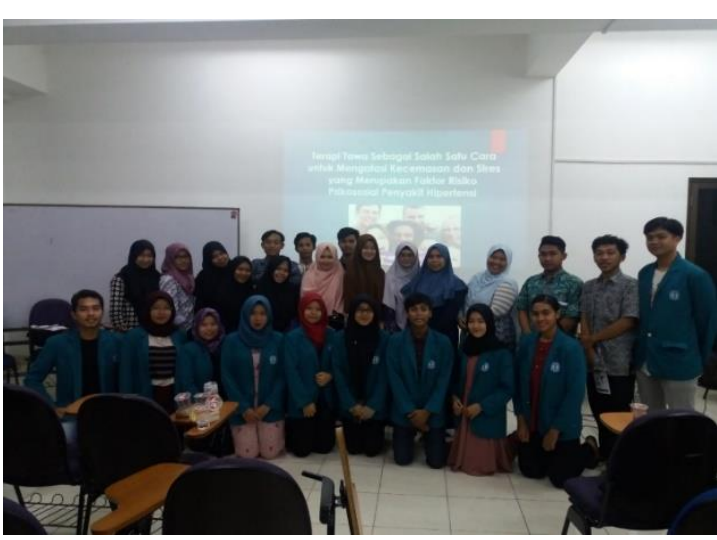

Gambar 3B. Foto Bersama selesai kegiatan Gambar 3: Antusiasme Peserta Dalam Menyimak Pemberian Pendidikan Kesehatan: Terapi Tawa 


\section{Kesimpulan}

Pendidikan Kesehatan yang diberikan kepada mahasiswa Mapala mendapat sambutan sangat baik dari mahasiswa terbukti dengan keaktifan peserta mengikuti pelatihan dengan tidak meninggalkan tempat sebelum waktu pelatihan berakhir. Berdasarkan hasil evaluasi menunjukkan bahwa dari 22 mahasiswa yang telah mengikuti kegiatan, memperoleh tambahan pengetahuan sebesar $10 \%$ sebanyak sembilan orang, $20 \%$ sebanyak tujuh orang, dan 0\% sebanyak enam orang. Saran bagi Mapala; diharapkan mampu mengimplementasikan ilmu yang telah didapatkan (terapi tawa) dan dapat menyebarluaskan ilmu kepada mahasiswa atau masyarakat pada umumnya.

\section{Ucapan Terima Kasih}

Ucapan terima kasih kami sampaikan kepada Kuswanto Hardjo, dr, M. Kes selaku Dekan Fakultas Kesehatan Universitas Jenderal Achmad Yani Yogyakarta yang telah memberikan support demi keberlangsungan acara ini.

\section{Daftar Pustaka}

[1] Nurhidayat S, Rosjidi CH. (2008). Buku Ajar Perawatan Cedera Kepala dan Stroke. Yogyakarta: Ardana Media.

[2] Philip, I \& Aaronson, J. (2010). The Cardiovascular System at a Glance. English: Blackwell Publishing Ltd.

[3] Desinta, S \& Ramadani, N. (2013). Terapi Tawa untuk Menurunkan Stres pada Penderita Hipertensi. Jurnal Psikologi. 40 (01). 15-27

[4] Yusuf, M. (2008). Kesehatan Mental. Bandung: Rizqi Press.

[5] Ahmad, A. (2009). Psikologi Umum. Jakarta: Rineka Cinta.

[6] Anwar. Z. (2015). Terapi tawa untuk Healing dan Recovery Trauma Pasca Bencana. Procedia Studi Kasus dan Intervensi Psikologi. 3 (1). 50-54.

[7] Prasetyo, AR dan Nurthahjanti, H. (2012). Pengaruh Penerapan terapi Tawa Terhadap Penurunan Tingkat Stres Kerja pada Pegawai Kereta Api. Jurnal psikologi Undip. 11 (1). 59-72

[8] Juhamsah, S. Widyastuti dan Ridfah, A. (2018). Terapi Tawa Terhadap Penurunan Tingkat Stres Akademik pada Mahasiswa Strata 1. Jurnal Psikologi Talenta. 4 (1). 80-89

[9] Sobur, A. (2013). Psikologi Umum. Bandung: CV. Pustaka Setia.

[10] Nurwela. TS, Mahajudin. MS dan Adiningsih. S. (2015). Efektivitas Terapi Tertawa Untuk Menurunkan Tingkat Depresi pada Lansia. Jurnal ilmiah Kedokteran. 4 (1). 62-76 